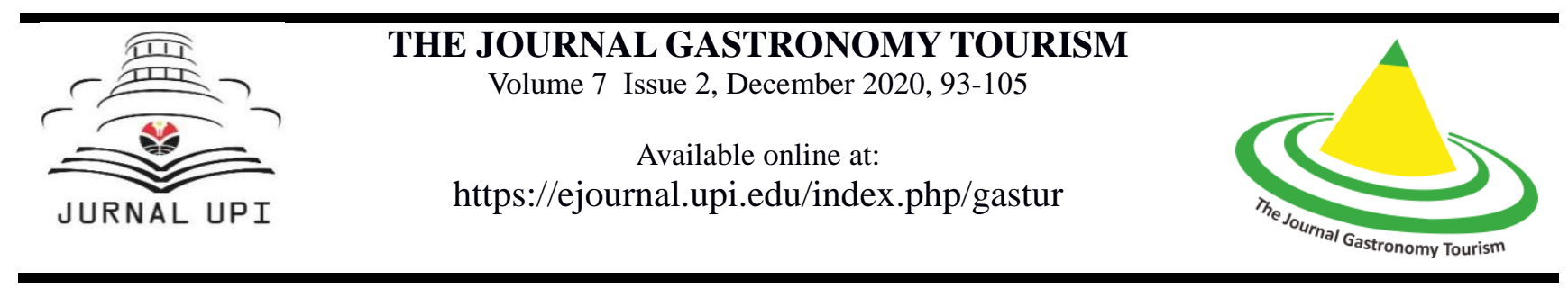

\title{
The Differentiation of Corn Choux Pastry Product with Additional Vegetables as Stuffing
}

\author{
Silvi Octavia ${ }^{1}$, Caria Ningsih ${ }^{1}$, Ilham Fajri ${ }^{2}$ \\ ${ }^{1}$ Catering Industry Management, Faculty of Social Science Education, University of \\ Education Indonesia, Jln. Dr. Setiabudhi No. 229, Bandung 40154, Indonesia \\ ${ }^{2}$ Bandung Tourism College, Jln. Dr. Setiabudhi No. 186, Bandung 40141, Indonesia \\ *Corresponding Author E-mail: silvioctavia@student.upi.edu
}

\begin{abstract}
Corn is Indonesian's staple food and the need for corn in the country is increasing. This can be seen from the corn fields that are scattered throughout the provinces. This condition has made Indonesia as one of the exporting countries of corn to several ASEAN countries. This study aims to make a differentiation of choux pastry with blended corn in the dough. The research method in this article is experimental. To test the product formulation and product quality, the opinions of the supervisors are employed. Lastly, descriptive test is used, and market analysis of the product is conducted. Samples of choux pastry formulations used the ratios of 50\%: 50\% and 25\%: $75 \%$ respectively between wheat flour and corn. Each formulation is tested by the supervisors to produce the average product which is most preferred by the supervisors. Furthermore, the product is tested again using market analysis to find out the public acceptance of the differentiation of corn choux pastry product with the addition of corn.

Keywords: Product Differentiation; Choux Pastry; Corn.
\end{abstract}

First Received: July 2020

Revised: August 2020

Accepted: September 2020

Final Proof Received: Oktober 2019

Published: December 2020 


\section{Introduction}

Indonesia is a country that has many islands dispersed from Sabang to Merauke, and is known as an archipelagic state. Therefore, Indonesia has many ethnicities and cultures which can serve as tourism destinations. Currently, many Indonesian are engaged in businesses related to tourism.

Tourism is a series of activities and the provision of services for various needs such as the need for tourist attractions, transportation, accommodation, and other things aimed at meeting the travel needs of a person or a group of people. The trip is only temporary, with the intention of resting, doing business, or other purposes (Sugiama, 2011).

Tourism is a variety of tourist activities, which are supported by various facilities and services provided by the community, local government and the central government (Law No. 10 of 2009 on tourism).

West Java itself has various tourist destinations, ranging from nature, shopping, to culinary tourism. Culinary tourism functions not only to satisfy and pamper the stomach with a variety of specialties from many places, but also as an interesting experience for someone in visiting and enjoying the food firsthand. The dining and cooking experience of each regional specialty makes the experience even more special.

Food is very influential in the tourism sector in Indonesia. It is not uncommon for tourists who visit an area would taste the specialties of that area. Indonesia is rich in regional culture, so it can be called a country rich in culinary delights. West Java also has many regions, and each of them has its own unique food. In fact, in each region, the food's raw materials are different from other regions. As time goes by, many foods have been differentiated by being added by various other ingredients in their manufacture without losing the taste and uniqueness of the original recipes. In economic term, it is called as product differentiation.

Corn is one of Indonesian's staple food. In fact, the productivity of corn in West Java always occupies the highest position compared to other provinces. Chairman of the National Corn Council (DJN), said that currently Indonesia can export corn to ASEAN countries, such as the Philippines and Malaysia. The corn production is also encouraged to meet the community needs. Until now, corn production is still deemed feasible and sufficient for its availability to cover national needs (Muhammad, 2019).

Corn production in Indonesia is classified as advanced compared to 22 areas classified as the largest corn centers in the country, such as East Java, South Sulawesi, Central Sulawesi, Lampung, Central Java, West Java, West Nusa Tenggara, and so on. Regarding corn production, the President of the Republic of Indonesia has revealed that in 2018, Indonesia was able to export 380 thousand tons of corn. Then, in 2014-2018 Indonesia was able to suppress corn imports by 3.3 million tons.

Table 1 Corn Production by Province in

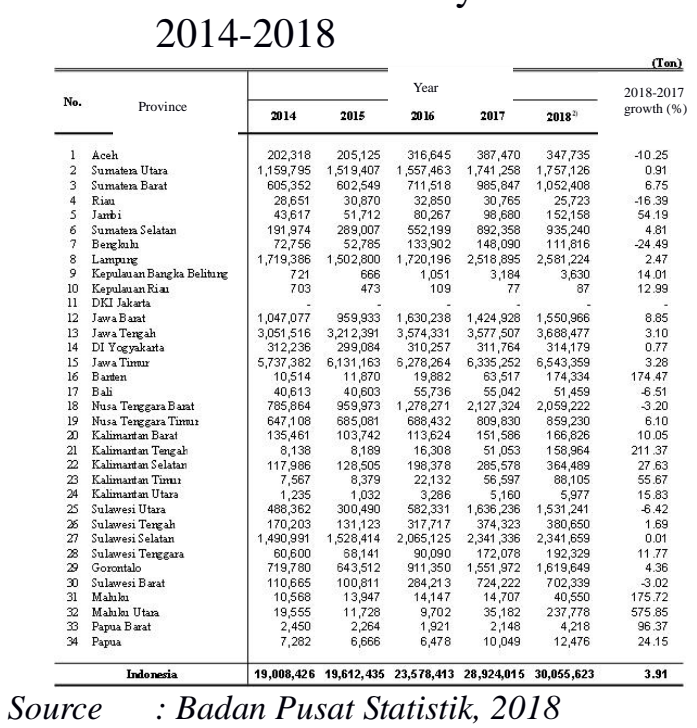

Based on data from the Badan Pusat Statistik (BPS) / Central Statistics Agency 
in table 1, national corn production is increased from 19 million tons in 2014 , to 19.6 million tons in 2015. The increase in corn production continued to soar in 2016 to 23.6 million tons, then continued in 2017 to 28.9 million tons. In 2018 it jumped again to reach 30 million tons. Meanwhile, the supply of corn as needed in Indonesia currently only reaches 7.811.1 million tons.

West Java is one of the areas with large land potential to be planted with corn commodities. According to the Head of the Food Crops and Horticulture of West Java, although it is not a corn-producing province in Indonesia, currently, in terms of productivity, the corn plant from West Java exceeds national production. (Jatnika, 2019). West Java itself has cities / regencies that have become corn centers, such as Nagreg Garut, Sumedang, and Majalengka. Dry land in Purwakarta, Karawang and Kuningan will also be developed into centers for corn production. Purwakarta has 30,000 hectares of land that is potential to be planted with corn. Differences in natural resources and local expertise in making food will produce a unique identity for a community group through food. (Ningsih, 2020)

One of the products that can use corn as a basic ingredient is choux pastry. The choux pastry itself is not that well known especially in Bandung due to the lack of sales of this product and the lack of public knowledge about this type of cake. Choux pastry is choux that can be topped or filled with various flas, fruits, or meats (Bogasari, 2013). Choux pastry is classified as a sponge cake and is a type of cupcake or muffin with ragout as its filling mixed with slices of chicken or beef with the addition of carrots or corn in it.

The differentiation of choux pastry products is beneficial to increase the selling power of corn and developing local foodstuffs. By utilizing corn as food, it also helps the economy of farmers in Indonesia. Corn is also very easy to get because corn is a local Indonesian plant and has spread throughout Indonesia. In addition, the price of corn is still relatively cheap and contains good nutritional values for the human body. In addition, the choux pastry product with additional corn ingredients will also help to preserve the corn itself and become a new public's choice of a healthy snack.

From the description above, the authors propose several research questions, namely:

a. What is the standard recipe for corn choux pastry with additional vegetables as stuffing?

b. What is the standard production cost of corn choux pastry with additional vegetables as stuffing?

c. What are the results of market analysis and organoleptic tests on corn choux pastry product with additional vegetables as stuffing?

\section{Literature Review}

\subsection{The Definition of Tourism}

Tourism is closely related to tourism and tourists. Tourism itself has a very broad meaning. Tourism is defined as a trip that is planned and carried out by individuals or groups from one place to another and aims to get satisfaction and pleasure (Sinaga, 2010).

Based on the definition above, it can be concluded that tourism is a travel activity, or other tourism activity, which aims to seek satisfaction and is supported by the existing facilities and services.

\subsection{The Definition of Culinary}

In general, culinary is an activity that is closely related to cooking (ChambersEsssential English Dictionary. Chambers Harrap Publishers Ltd: 1995). In English, the word culinary means something that happens in the kitchen which is related to cooking (Anthropologi Kuliner Nusantara Jakarta:kpg, 2015). Culinary is closely related to food. Food itself is a basic 
human need. However, nowadays, there are so many foods that may not be given attention from a nutritional perspective. Many people are turning to fast food despite its negative impact on health. In addition, people also like to hunt for sweets, such as cakes.

\subsection{The Definition of Cake}

Cake is popular among the people. Currently, many regions in Indonesia make cakes as specialties. Cake dough is a complex emulsion and foam system, namely flour, milk, fat, sugar, eggs, and leavening agents as the main ingredients used in its making (Turabi et al., 2010).

\subsection{Cake Ingredients}

The ingredients for making cakes include wheat flour, fat, sugar and eggs. The following is an explanation and function of each ingredient:

a. Wheat flour

Flour is the most important ingredient in making cakes which functions as a structure and binder for other ingredients (Krissetiana, 2013). Wheat flour is divided into three types, namely low protein flour (soft flour) with a protein content of 7-9\%, medium protein flour (medium flour) with a protein content of $9-11 \%$, and high protein flour (hard flour) with protein content of 11-13\% (Subagjo, 2007: 20).

b. Fat

Fat is very important in the cake making process. There are several kinds of fat in the cake-making process, namely Butter, Margarine, and Oil

c. Sugar

One of the important ingredients in the cake-making process here is sugar which functions as a sweetener. Apart from providing a sweet taste, sugar also provides an aroma and is a natural preservative.

d. Egg

Eggs function as a structure formation in the cake, add nutritional value, add flavor, and make the cake softer.

\subsection{Sweet Corn}

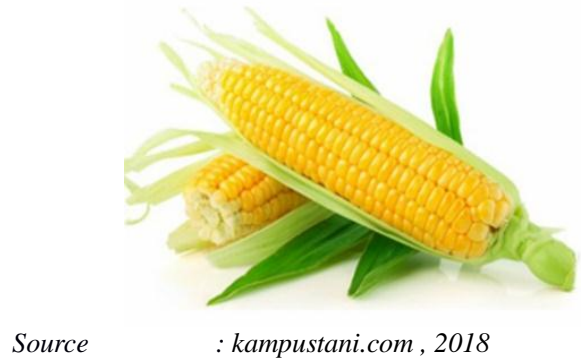

Figure 1 Sweet Corn

Sweet corn is a CGPRT commodity and belongs to the Gramineae (grass) family, Zea genus, and the Zea Mays Saccharata species. The main product of sweet corn is the fruit / cobs, sweet corn kernels also have varied shape, color and endosperm content depending on the type. Sweet corn kernels consist of three main parts, namely the seeds (seed coat), endosperm, and embryos (Koswara, 2009). Corn is included in the category of annual crops. One cycle is completed in 80-150 days.

\subsection{Vegetables}

Vegetables are one of the most important foods for humans. Apart from fruits, protein, carbohydrates, vegetables also contain essential ingredients for the body, such as fiber and vitamins. Vegetables also have various types to be used as cooking ingredients, stuffing ingredients, or as snacks. Vegetables usually high in water and are consumed fresh or minimally processed.

\subsection{Product Differentiation}

Differentiation as a company's effort aims to create differences among its competitors in order to form the best value to customers (Kartajaya, 2004). Product differentiation is one of the company's efforts to differentiate its products from competitors' products in a trait to increase consumers' interest (Madura, 2001). In brief, product differentiation is an effort by the company or producer to increase 
consumer's interest by differentiating the product with the pre-existing ones.

\subsection{Packaging}

Packaging is an activity that involves design and production, Packaging functions to protect the products contained in it (Kotler and Amstrong, 2012). Packaged products are usually products that will be distributed, stored, sold and used. Packaging also serves as a good means of information and marketing, especially if it is designed creatively and attractively, so that it is easy for consumers to remember.

\subsection{Product Quality}

Quality or value is a measure of good and bad assessments which can affect a product or service. Every individual has different views and benchmarks on the quality of products and services. This is because quality has many dimensions, depending on the individual who assesses it. Quality is the totality of the features and characteristics of a product or service that bears on its ability to satisfy implicit or explicit needs (Kotler and Keller, 2012). Meanwhile, products are everything that can be offered to the market to meet the needs and desires of consumers (Sangadji, 2013). Product quality is a combination of product characteristics in marketing, planning (engineering), product (manufacturing), and maintenance that the product uses to meet the expectations of consumers (Feingenbaum in Marwanto, 2015). Marsum (2005) stated that there are several things that needed by a product, namely taste, consistency, nutritional content, composition, eye appeal, aroma appeal, and temperature.

\subsection{Market Analysis}

\subsubsection{Definition of Market}

Market (market) is a meeting place of sellers and buyers. It is also defined as a place where supply and demand occur to achieve a price agreement. A business actor needs to understand the needs of consumers and what consumers want, so that the business actor is able to make good decisions for the next step. Kotler and Armstrong (2016) state that there are five core concepts that cover consumers and markets, namely:

a. needs, wants and requests;

b. marketing offerings include goods, services, and experiences;

c. value and satisfaction;

d. exchanges and relationships;

e. market.

\section{Materials and Methods}

The research method must be determined by the researcher before carrying out the research in order to provide an overview and direction in the research. The research method is a method used to obtain solutions to various research problems (Cresweel, 2010). Meanwhile, another opinion states that the research method is basically a scientific way to obtain data with specific purposes and uses (Sugiyono, 2012). In this study the authors used experimental research methods.

In conducting this research, the collected data is in the form of information related to the problem to be studied. Descriptive research is employed as the specification is descriptive in nature which aims to raise facts, circumstances, variables, and phenomena that are happening today and present them as they are (Subana, 2009). Descriptive research is conducted to determine the value of the independent variable, either one or more (independent) variables without making comparisons or connecting other variables (Sugiyono, 2013). Descriptive research to provide a description of:

a. The differentiation of corn choux pastry product using additional corn.

b. Market analysis of the product

In this study, the authors obtained data using a questionnaire in which then the data is calculated and concluded. 


\section{Discussion}

After conducting the product tests, conclusions can be drawn regarding the superior product based on the aspect of product quality to determine the best recipe formula. The results of the study include the formulation of recipes, production processes, nutritional value of products, and product packaging. The test was carried out on thirty expert and trained panelists consisting of chefs, academics, and entrepreneurs in the culinary field. The treatment of corn choux pastry has the following formulations:

a. Corn choux pastry (SMJ 1)

The addition of corn in the first recipe formulation is $25 \%$ in one dough recipe.

b. Corn choux pastry (SMJ 2)

The addition of corn in the second recipe formulation is $50 \%$ in one dough recipe.

c. Corn choux pastry (SMJ 3)

The addition of corn in the third recipe formulation is $75 \%$ in one dough recipe.

After testing the product, the researchers create an assessment of the product. The first stage carried out is the organoleptic test through questionnaire to expert panelists containing self-identity, and responses to the product. For the product response section, there are scores on a scale from one to five. With a scale description as follows:

Scale 5: I love it

Scale 4: I like it

Scale 3: I quite like it

Scale 2: I dislike

Scale 1: I detest

After making the questionnaire, the authors provide product samples based on three recipe formulas that would be tested, along with an organoleptic test assessment questionnaire, to expert panelists, namely chefs, academics, and entrepreneurs in the culinary field. The results of the assessment based on a questionnaire from all expert panelists are then recapitulated.

\subsection{Overview of Research Objects}

The object of this research is the experimental recipe for corn choux pastry. Three samples are provided as comparisons of the recipes, namely $25 \%$, $50 \%$, and $75 \%$ using corn. After conducting trials of the three sample recipes, the best recipe would be selected in order to produce the best product based on the organoleptic tests by the expert panelists. Furthermore, the nutritional values contained in the product are calculated as well as per package selling price.

\subsection{Organoleptic Test}

Organoleptic assessment is conducted by carrying out three treatments of product samples which were given the addition of corn to expert and trained panelists, consisting of thirty people ranging from chefs, academics, practitioners, culinary students, to food entrepreneurs. In this study, the sample product of corn choux pastry is coded as SMJ (Sus Maker Jagung). Here are the details of the three product samples:

a. Corn choux pastry (SMJ 1)

The addition of corn in the first formulation is $25 \%$ in one dough recipe

b. Corn choux pastry (SMJ 2)

The addition of corn in the second formulation is $50 \%$ in one dough recipe

c. Corn choux pastry (SMJ 3)

The addition of corn in the third formulation is $75 \%$ in one dough recipe.

The final results of the treatment of the three corn choux pastry formulations are attached in the following table: 
Table 2. Result of Expert Panelist Test on Corn Choux Pastry

\begin{tabular}{|c|c|c|c|c|c|c|c|}
\hline \multirow{2}{*}{ Formulation } & \multicolumn{6}{|c|}{ Assessment Aspects of the SMJ } & \multirow{2}{*}{ Total } \\
\hline & Taste & Aroma & Texture & Shape & Appearance & Packaging & \\
\hline SMJ 1 & 6,5 & 6,7 & 6,2 & & & & 36,8 \\
\hline SMJ 2 & 7,4 & 7,5 & 7,2 & 8,7 & 4,3 & 4,4 & 39,5 \\
\hline SMJ 3 & 8,9 & 9 & 8,8 & & & & 44,1 \\
\hline
\end{tabular}

Souce: Processed data, 2020

Table 2 shows the total of mean values for the three recipe formulations, which consist of the characteristics of taste, aroma, texture, shape, appearance, and packaging. Based on these data, the most superior is found in the SMJ 3 recipe formulation with an average value of 44.1 .

\subsection{The Calculation of Nutritional Values of Corn Choux Pastry}

The nutritional values content in corn choux pastry can be seen in the table below

Table 3. Calculation of Nutritional Values of Corn Choux Pastry (Portion : 10 portion)

\begin{tabular}{lccccc}
\hline \multirow{2}{*}{ Ingredients } & \multirow{2}{*}{ Quantity } & Energy & Protein & Fat & Carbohydrate \\
\cline { 2 - 6 } & $75 \mathrm{~g}$ & $\mathbf{K c a l}$ & $\mathbf{g}$ & $\mathbf{g}$ & $\mathbf{g}$ \\
\hline Wheat flour & 3 & 45 & 6,7 & 1 & 58 \\
Egg whites & 5 & 361 & 16,72 & 0 & 0,72 \\
Yolks & $60 \mathrm{~g}$ & 218,4 & 0 & 31,90 & 0,7 \\
Sugar & $10 \mathrm{~g}$ & 50,9 & 2,46 & 0 & 56,4 \\
Milk powder & $30 \mathrm{~g}$ & 216 & 0,18 & 24,3 & 3,62 \\
Butter/ melted margarine & $60 \mathrm{~g}$ & 57,6 & 2,1 & 0,6 & 0,12 \\
Blended sweet corn & & & & & 13,68 \\
Filling Ingredients & $20 \mathrm{~g}$ & 144 & 0,12 & 16,2 & 0,08 \\
Margarine & $30 \mathrm{~g}$ & 14,36 & 0,44 & 0,06 & 3,28 \\
Onion & $30 \mathrm{~g}$ & 109,5 & 2,67 & 0,39 & 23,19 \\
Wheat flour & $50 \mathrm{~g}$ & 260 & 15,68 & 21,55 & 0 \\
Ground chicken & $150 \mathrm{ml}$ & 753 & 40,5 & 39 & 60 \\
Milk & $20 \mathrm{~g}$ & 9,54 & 0,27 & 0,06 & 2,11 \\
Carrot & $20 \mathrm{~g}$ & 19,52 & 0,47 & 0,02 & 4,49 \\
Potato & & $\mathbf{2 . 5 3 2 , 5 7}$ & $\mathbf{9 7 , 5 8}$ & $\mathbf{1 3 8 , 0 8}$ & $\mathbf{2 2 6 , 3 9}$ \\
Amount of nutrition & & & & & \\
\hline
\end{tabular}

Source: Processed data, 2020

The table above is the result of the nutritional value calculation based on a recipe for corn choux pastry. One recipe of the dough can produce 10 portions, the nutritional value in one serving of the choux is as follows:

$$
\begin{gathered}
\text { Energy }: 253 \mathrm{kCal} \\
\text { Protein }: 10 \text { grams or equivalent to } 40 \\
\mathrm{kCal}
\end{gathered}
$$

Fat : 14 grams or equivalent to 126

$$
\mathrm{kCal}
$$

Carbs : 23 grams or equivalent to 92 $\mathrm{kCal}$

\subsection{Product Packaging Design}

The packaging serves to protect as well as a medium for information about the corn choux pastry. The product is packaged using aluminum foil cup and boxes made of paper. The packaging contains information about nutritional content, composition, product net weight, product logo, storage method, production date and expiration date. 


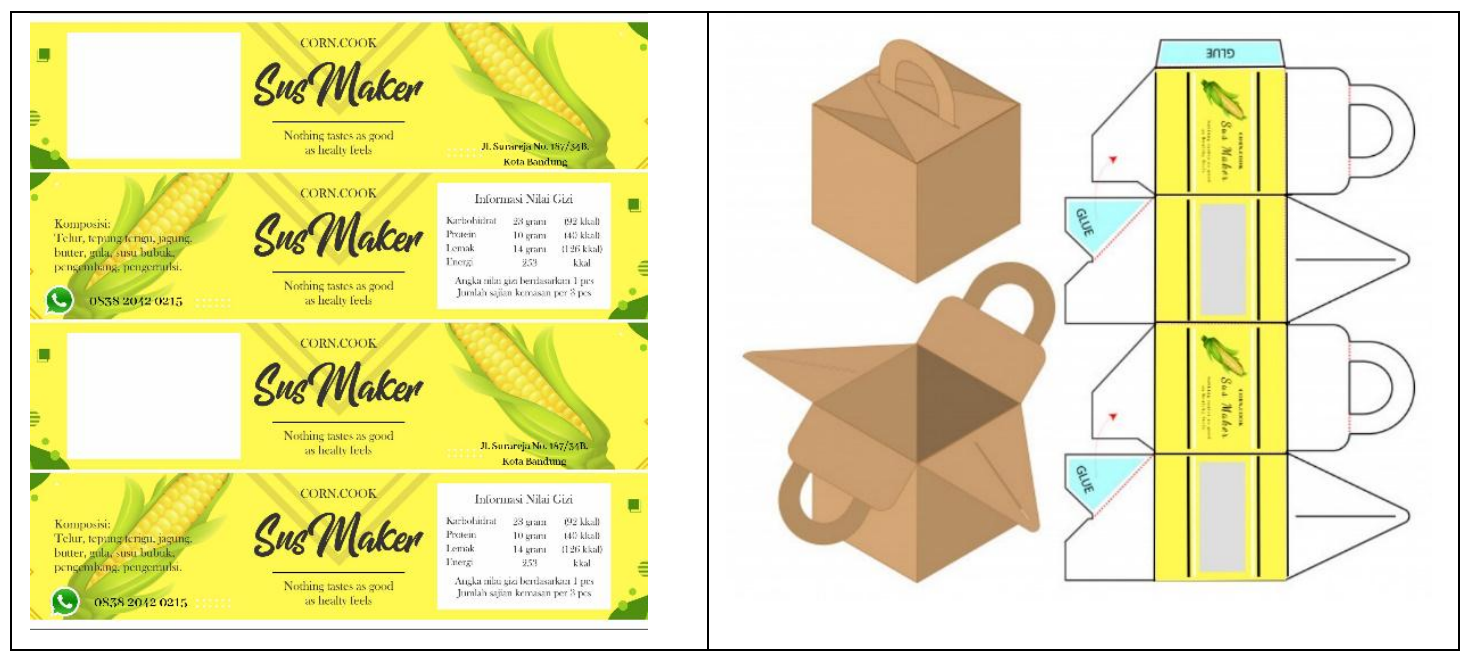

Figure 2 Packaging Design and Product Logo

4.5. Product Selling Price Calculation

\subsubsection{The Cost of Sales of The Corn Choux Pastry Product}

The cost of production of corn choux pastry can be seen in the following table:
Based on Table 5 below, the total cost for the raw materials for making corn choux pastry for ten portions is IDR $33,100.00$, while the price per portion is IDR 4,965.00 or IDR 5,000.00. This price has included packaging and labeling costs.

Tabel 5. Food Cost of Corn Choux Pastry

\begin{tabular}{|c|c|c|c|c|c|}
\hline \multicolumn{6}{|c|}{ STANDARD RECIPE } \\
\hline \multicolumn{2}{|c|}{ Product : Corn Choux Pastry } & \multicolumn{4}{|c|}{ Cooking time: 90 minutes } \\
\hline \multicolumn{2}{|c|}{ Portion : 10 portion } & \multicolumn{4}{|c|}{ Cooking method: Baking } \\
\hline NO & INGREDIENTS & QTY & UNIT & UNIT PRICE & TOTAL PRICE \\
\hline 1 & Wheat flour & $75 \mathrm{~g}$ & $\mathrm{Kg}$ & IDR 10,000 & IDR 750 \\
\hline 2 & Egg white & 3 & $\mathrm{Kg}$ & IDR 2,000 & IDP 1000 \\
\hline 3 & Egg yolk & 5 & $\mathrm{Kg}$ & IDR 2,000 & ШUत 10, \\
\hline 4 & Sugar & $60 \mathrm{~g}$ & $\mathrm{Kg}$ & IDR 12,000 & IDR 720 \\
\hline 5 & Milk powder & $10 \mathrm{~g}$ & Sch & IDR 3,000 & IDR 3,000 \\
\hline 6 & Baking powder & $10 \mathrm{~g}$ & Pcs & IDR 6,000 & IDR 6,000 \\
\hline 7 & Emulsifier & $10 \mathrm{~g}$ & Ons & IDR 6,000 & IDR 6,000 \\
\hline 8 & Melted margarine & $30 \mathrm{~g}$ & $\mathrm{Kg}$ & IDR 16,000 & IDR 480 \\
\hline 9 & Sweet Corn & $60 \mathrm{~g}$ & $\mathrm{Kg}$ & IDR 6,000 & IDR 360 \\
\hline \multicolumn{6}{|c|}{ STUFFING INGREDIENTS } \\
\hline 11 & Margarine & $20 \mathrm{gr}$ & $\mathrm{Kg}$ & IDR 16,000 & IDR 320 \\
\hline 12 & Onion & $30 \mathrm{gr}$ & $\mathrm{Kg}$ & IDR 20,000 & IDR 600 \\
\hline 13 & Wheat flour & $30 \mathrm{gr}$ & $\mathrm{Kg}$ & IDR 10,000 & IDR 300 \\
\hline 14 & Chicken fillet & $50 \mathrm{gr}$ & $\mathrm{Kg}$ & IDR 30,000 & IDR 1,500 \\
\hline 15 & Milk & $150 \mathrm{ml}$ & $\mathrm{L}$ & IDR 17,000 & IDR 2,550 \\
\hline 16 & Carrot & $20 \mathrm{gr}$ & $\mathrm{Kg}$ & IDR 10,000 & IDR 200 \\
\hline \multirow[t]{3}{*}{17} & Potato & $20 \mathrm{gr}$ & $\mathrm{Kg}$ & IDR 16,000 & IDR 320 \\
\hline & & & & Total & IDR 33,100 \\
\hline & & & & Food cost $(50 \%)$ & IDR 33,100 \\
\hline
\end{tabular}




\begin{tabular}{|c|c|c|}
\hline \multicolumn{3}{|c|}{ Source: Processed data, 2020} \\
\hline \multicolumn{3}{|c|}{$\begin{array}{l}\text { 4.5.2. Selling Price of The Corn Choux } \\
\text { Pastry Product }\end{array}$} \\
\hline \multicolumn{3}{|c|}{$\begin{array}{l}\text { The selling price of the product can } \\
\text { be seen in the table below: }\end{array}$} \\
\hline \multicolumn{3}{|c|}{ Tabel 6. Harga Jual Corn choux pastry } \\
\hline Food Cost & $\mathbf{5 0 \%}$ & IDR 33.100 \\
\hline Labour Cost & $15 \%$ & IDR 4.965 \\
\hline Overhead & $15 \%$ & IDR 4.965 \\
\hline Net Profit & $20 \%$ & IDR 6.620 \\
\hline Selling Price & $100 \%$ & IDR 49.650 \\
\hline
\end{tabular}

Source: Processed data 2020

The cost of sales for the production of corn choux pastry with vegetable filling is IDR 33,100 with a percentage of $50 \%$, labor cost IDR 4,965.00 with a percentage of $15 \%$, overhead IDR 4,965.00 with a percentage of $15 \%$, and a net profit of IDR $6,620.00$ with a percentage of $20 \%$. Details of the calculation of the selling price are as follows:

\begin{tabular}{|lll|}
\hline Harga Jual $=$ & $\begin{array}{l}\text { Persentase } \text { selling price } \\
(100 \%)\end{array}$ & $\begin{array}{c}\text { x jumlah } \\
\text { food cost }\end{array}$ \\
\cline { 2 - 3 } & Persentase food cost & \\
\hline
\end{tabular}

a. Food Cost

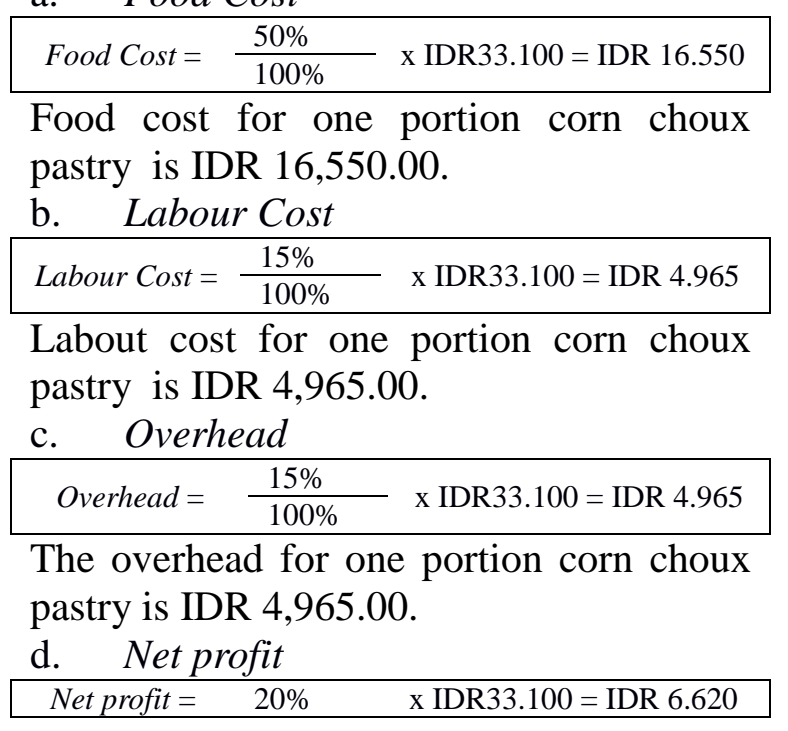

\section{Overhead (15\%) IDR 4,965 \\ Labour cost (15\%) IDR 4,965 \\ Net profit(20\%) IDR 6,620 \\ Selling price $(100 \%) \quad$ IDR 49,650 \\ Selling price/10 portion IDR 4,965}

Accordingly, the profit obtained from the sale of corn choux pastry is IDR 6,620.00 / pack.

\subsection{Market Analysis}

In accordance with the market analysis described previously, the formulation of a market analysis consists of segmentation, targeting, and positioning. The following is a description of the market analysis for the product:

\section{a. Market Segmentation}

Geographically, the market segmentation of this corn choux pastry is people living in the city of Bandung. Demographically, the market segmentation for this product is for all ages. Meanwhile, psychologically, the market segmentation for this product are consumers who want to eat a type of cake with a different taste with vegetables stuffing and consumers who want to enjoy a new variant of a product that has existed before.

\section{b. Market Positioning}

Researchers will position the corn choux pastry as a product that is of interest to the public in various aspects of the assessment by making attractive packaging, producing the best quality products, and positioning the corn choux pastry as a type of healthy snack.

\section{c. Target Market}

The main target of the corn choux pastry product is for all people who wish to try a cake filled with roughout which has a savory taste and is different from other cakes. Currently, researchers are targeting employees, college students, and school students as consumers by introducing the product first. In addition, 
distribution will be carried out online through social media, such as using Instagram, WhatsApp and Facebook

\section{Conclusions}

Determining three comparison sample recipes of $25 \%$ (recipe sample one), $50 \%$ (sample recipe two), and $75 \%$ (sample recipe three). Then a recipe test is conducted to find out which recipe had the best results in terms of taste, aroma, color, shape, appearance and texture based on organoleptic tests by thirty expert and trained panelists.

Determining the packaging design for the product. The corn choux pastries are baked in a round aluminum foil cups, then packaged in a food box with a logo sticker and nutritional value information.

Determining the selling price of the product, namely IDR 5,000.00 / pcs and IDR 15,000.00 / pack containing three pacs of chouxs. The price is calculated by the percentage of $50 \%$ food cost, $15 \%$ labor cost, overhead cost $15 \%$, and $20 \%$ profit.

Determining the market analysis through geographical, demographical, and psychological segmentation of potential customers, as well as by conducting STP (Segmentation, Target, and Position) analysis. Geographically, the market segmentation of this corn choux pastry product is the people who live in Bandung area and its surroundings. Demographically, the market segmentation for this product is all ages. Psychologically, the market segmentation is consumers who want to consume muffin cake as a healthy snack, as well as as an appetizer or dessert, and consumers who want to enjoy a new differentiated product of a pre-existing one.

\section{References}

Amelia, J. R., Ma'arif, S., \& Arkeman, Y. (2016). Yoghurt Susu Jagung Manis Kacang Hijau Sebagai Strategi Inovasi Produk Alternatif Pangan
Fungsional. Jurnal

Industri, 4(3).

Teknik

Arikunto, Suharsimi. (2005). Manajemen Penelitian. Jakarta: Rineka Cipta.

Arikunto, S., (2009). Prosedur Penelitian Suatu Pendekatan Praktik. Edisi Revisi 6. Jakarta : Rineka Cipta.

Astina, S. T., Sunarti, \& Mawardi, M. K. (2016). Analisis Segmentation, Targeting, dan Positioning dalam Rangka Meningkatkan Daya Saing Melalui Strategi Pemasaran di Toko Pia Cap Mangkok Semeru. Journal Administrasi Bisnis (JAB), Vol.39 No.2.

A.W Marsum. 2005. Restoran dan Segala Permasalahannya. Edisi Empat. Yogyakarta: Andi.

Azwar, Saifuddin. (2007). Metode Penelitian. Pustaka Pelajar: Yogyakarta.

Badan Pusat Statistik. (2018). Produksi Tanaman Jagung Menurut Provinsi. https://bps.go.id/linkTableDinamis/vi ew/id/868. Diakses tanggal 5 Januari 2020.

Badan Pusat Statistik. (2018). Produktivitas Tanaman Jagung Menurut Provinsi. https://bps.go.id/linkTableDinamis/vi ew/id/868. Diakses tanggal 5 Januari 2020.

Bahrum, S. (2018). Makalah Jagung Manis.

Bartono,P.H dan Ruffino,E.M. (2005). Food Product Management di Hotel dan Restoran. Yogyakarta: C.V Andi Offset.

Cenadi, C. S. (2004). Peranan desain kemasan dalam dunia pemasaran. Nirmana, 2(2).

Creswell, J. W. (2010). Research design: pendekatan kualitatif, kuantitatif, dan mixed. Yogjakarta: PT Pustaka Pelajar.

Daryanto. 2011. Manajemen Pemasaran: Sari Kuliah. Bandung: Satu Nusa.

Depdikbud, (1989), Kamus Besar Bahasa Indonesia, Buku Satu, Jakarta: Balai 
Pustaka Utama.

Devi Puspita Sari dan Audita Nuvriasari (2018). Pengaruh Citra Merek, Kualitas Produk Dan Harga Terhadap Keputusan Pembelian Produk Merek Eiger (Kajian Pada Mahasiswa Universitas Mercu Buana Yogyakarta).

Dictionary, C. (1993). Chambers Harrap Publishers Ltd. Google Scholar, 383.

Drummond, Karen Eich, Joseph F. Vastano, and Josephine C. Vastano. Cook's Healthy Handbook. New York: John Wiley \& Sons, 1993.

Duncan, Tom. 2008. Principles of advertising and IMC $2^{\text {nd }}$ edition. Mc. Graw-Hill International Edition.

Ginting, Hartimbung. Manajemen Pemasaran. Bandung: CV Yrama Widya, 2011.

Hagstrum, D. W., \& Heid Jr, W. G. (1988). US wheat-marketing system: An insect ecosystem. Bulletin of the ESA, 34(1), 33-37.

Hair et al. 2010.Multivariate Data Analysis.(7th edition). New Jersey:Pearson Education Inc.

Hamdi, A. S., \& Bahruddin, E. (2015). Metode penelitian kuantitatif aplikasi dalam pendidikan. Deepublish.

Hendi, Jatnika (2019). Https://jabarnews.com/read/6333/jag ung-menjadi-tanaman-yang-banyakdiminati-petani-setelah-padi. Diakses tanggal 5 Januari 2020.

Hendrasty, H. H. K. (2003). Teknologi Pengolahan Pangan: Tepung Labu Kuning. Kanisius.

Inglett, G.E. (1987). Corn, Culture, Processing, Products. The avl Publ, Co. Inc : Westport, Connecticut.

James, Spillane, J. (1982). Pariwisata Indonesia, Sejarah dan Prospeknya. Yogyakarta: Kanisius.

Jihan Nafisa Dan I Made Sukresna. 2018: Analisis Pengaruh Kualitas Layanan, Harapan Kinerja dan Citra
Perusahaan Terhadap Loyalitas

Pelanggan Melalui Kepuasan

Pelanggan Sebagai Variabel Intervening (Studi Kasus Pada Percetakan Digital di Malang), Diponegoro Journal of Management, Vol 7, No. 3, 1-26.

Kamil, J. (1982). Teknologi Benih. Buku. Angkasa Bandung. Bandung. 227 p.

Kartajaya,Hermawan.2004. Differentiatin. Bandung: Mizan.

Koswara. (2009). Respons Pertumbuhan Dan Produksi Tanaman Jagung Manis (Zea mays saccharata Sturt) Terhadap Pemberian Pupuk Cair Tnf Dan Pupuk Kandang Ayam. Balai Penelitian Tanah.

Kotler,Philip and Gary Armstrong. (2008). Prinsip-prinsip Pemasaran. Edisi. 12. Jilid 1. Jakarta: Erlangga.

Kotler, P. and K. L. Keller 2012. Marketing management. Upper Saddle River, N.J., Prentice Hall.

Kotler, Philip and Armstrong, Gary. 2012. Prinsip-prinsip Pemasaran. Jakarta: Erlangga.

Kotler, Phillip, \& Amstrong, G. (2008). Prinsip-Prinsip Pemasaran (18th ed.). Penerbit Erlangga.

Krissetiana, H. (1995). Tepung Labu Kuning Pembuatan dan Pemanfaatannya. Kanisius, Yogyakarta.

Kurniawati, Y. I. (2017). Analisis Pengaruh Inovasi Produk, Iklan, Dan Citra Merek Terhadap Minat Beli Ulang Produk Mie Instan Indomie (Studi kasus pada Mahasiswa STIE PGRI Dewantara Jombang) (Doctoral dissertation).

Lamadlauw, Fanny Noviany. Dan Arief, Abd. Rahman. (2004). Pastry and Bakery Production. Yogyakarta: Graha Ilmu.

Madura, Jeff. 2001. Pengantar Bisnis. Jakarta: Salemba Empat.

Marsum WA. 2005. Restoran dan Segala Permasalahannya. Edisi IV. Yogyakarta : Andi. 
Marwanto, Aris. 2015. Marketing Sukses. Yogjakarta: KOBIS.

Maulana, A. I. (2017). Pengaruh Jenis Pupuk Kandang Dan Dosis Mikoriza Vesikular Arbuskular Terhadap Pertumbuhan Serta Hasil Jagung Manis (Zea mays Saccharata Sturt L.) (Doctoral dissertation, University of Muhammadiyah Malang).

Mayne, ST. (1996). Beta-Carotene, Carotenoids, and Disease Prevention in Humans. The FASEB Journal. Vol 10 May 1996

Muhammad,

Fadel

(2019).

Https://republika.co.id/berita/pwp30

7453/tak-perlu-impor-produksi-

jagung-ri-mencukupi-kebutuhan.

Diakses tanggal 5 Januari 2020.

Mukhtar, S., \& Nurif, M. (2015). Peranan Packaging Dalam Meningkatkan Hasil Produksi Terhadap Konsumen. Jurnal Sosial Humaniora, 8(2), 181-191.

Mursid.2014. Manajemen Pemasaran.bumi Aksara: Jakarta.l

Ningsih, Caria (2020), Pelestarian dan Pengembangan Kampung Nikmat Cigugurgirang sebagai Destinasi Wisata Warisan Budaya Gastronomi Sunda. Tourism Scientific Journal Vol.5 No.2, hlm 265-275 http://www.jurnal.stiepar.ac.id/index. php/tsj/article/view/97

Pantzaris. (1995). Principle of Barley Chemistry. Wiley Eastern Private Ltd. New Delhi.

Philip Kotler and Gary Amstrong (2016). Principles of Marketing sixteenth edition. England : Pearson Education Limited.

Pieter Gunawan Widjaya, "Analisis Segmenting, Targeting, Positioning dan Marketing Mix pada PT. Murni Jaya", Jurnal Agora, Vol. 5, No. 1, (2017).

Rangkuti, F. (1998). Analisis SWOT teknik membedah kasus bisnis. Gramedia Pustaka Utama.

Rifianto Azis, Sykur, Jagung Manis,
Penebar Swadaya Perum, Jakarta: Bukit Permai:, 2013.

Sahetapy, Joefar. 2013. Diferensiasi produk, strategi merek, pengaruhnya terhadap keputusan pembelian meubel UD Sinar Sakti Manado. Jurnal EMBA, Vol.1, No.3.

Sangadji. 2013. Prilaku Konsumen: Pendekatan Praktis Disertai: Himpunan Jurnal Penelitian. Penerbit Andi, Yogyakarta.

Sastradipoera, Komaruddi. (2003). Manajemen Marketing. Suatu Pendekatan Ramuan Marketing. Kappa Sigma. Bandung.

Soekarto. (1981). Penilaian Organoleptik Untuk Industri Pangan dan Hasil Pertanian. Jakarta : Bharat Aksara.

Suarni, S., Balai Penelitian Tanaman Serealia, M., Yasin, M., \& Balai Penelitian Tanaman Serealia, M. (2019). Jagung sebagai sumber pangan fungsional.

Subagyo, A. (2007). Studi kelayakan. Elex Media Komputindo.

Subagjo, A. 2007. Manajemen Pengolahan Kue dan Roti. Yogyakarta: Graha Ilmu.

Subana, Sudrajat, 2005, Dasar-Dasar Penelitian Ilmiah, Bandung: Pustaka Setia.

Sugiama, A Gima (2011), Ecotourism: Pengembangan Pariwisata Berbasis Konservasi Alam, Guardaya Intimarta, Bandung.

Sugiyono, (2008). Metode Penelitian Kunatitatif Kualitatif dan $R \& D$. Bandung Alfabeta.

Sugiyono. (2009). Metode Penelitian Bisnis (Pendekatan Kuantitatif, Kualitatif, dan $R \& D)$. Bandung: Alfabeta.

Sugiyono. (2012). Metode Penelitian Kuantitatif, kualitatif dan $R \& D$. Bandung:Alfabeta.

Sugiyono. (2013). Metode Penelitian Pendidikan Pendekatan Kuantitatif, Kualitatif, dan $R \& D$. Bandung: Alfabeta. 
Sugiyono. (2014). Metode Penelitian Pendidikan Pendekatan Kuantitatif, Kualitatif, dan $R \& D$. Bandung: Alfabeta.

Sukma, V. E., \& Dewi, P. E. (2018). Pendampingan Pengabdian Kepada Masyarakat Untuk Pelatihan Peraktik Pembuatan Produk Makanan Dari Jagung Serta Cara Pengemasannya. Jurnal Abdikarya: Jurnal Karya Pengabdian Dosen dan Mahasiswa, 1(1).

Sulandari, E. (2019). Pendahuluan 11.1. Pangan, Kebangsaan, dan Ketahanan Nasional, 103.

Supranto, J. (2000). Statistik Teori dan Aplikasi. Edisi I. Jilid I. Jakarta: Erlangga.

Supriyanto, S. P. (2006). Susu Baru, Jagung Manis.

Spillane, J. J. (1991). Ekonomi pariwisata: sejarah dan prosepeknya. Kanisius.

Susilowati. (2001). Pengaruh pupuk kalium terhadap pertumbuhan dan hasil tanaman jagung manis (Zea mays saccharata Sturt). Jurnal budidaya pertanian. Vol.7(1):36-45.

Syah, D., Kusnandar, F., \& Rahman, A. N. (2014). Pengembangan Model Kemitraan Agroindustri Jagung Terpadu (Pilot Plan Di Kabupaten
Takalar, Sulsel).

Tjiptono dan Chandra (2012). Market Targeting. Jakarta: Penerbit Erlangga.

Tjiptono \& Chandra, G. ( 2012). Pemasaran Strategik. Edisi Kedua. Yogyakarta Yogyakarta: ANDI.

Tjitrosoepomo, C. (1991). Taksonomi Tumbuhan. Yogyakarta: UGM Press.

Ulum, M. (2013). Dinamika Populasi Dan Aktivitas Bakteri Nitrifikasi Pada Tanah Alfisol Dengan Berbagai Kombinasi Masukan Seresah Menggunakan Tanaman Uji Jagung.

US. Wheat Associates (1983). Pedoman Pembuatan Roti dan Kue. Jakarta, Penerbit DJamatan.

Utama, I. G. B. R., \& SE, M. (2015). Pengantar Industri Pariwisata. Deepublish.

Widayati, C. S. W. (2009). Komparasi beberapa metode estimasi kesalahan pengukuran. Jurnal Penelitian dan Evaluasi Pendidikan, 13(2).

Wijaya, P. P., Yogha, S., \& Mahmudatussa'adah, A. Daya Terima Donat Buah Naga Merah Sebagai Produk Yeast Dough. Media Pendidikan, Gizi, dan Kuliner, 8(1). 